Marquette University

e-Publications@Marquette

College of Education Faculty Research and

Publications

Education, College of

$12-1-2004$

Self-Regulation in a Web-Based Course: A Case Study

Joan Whipp

Marquette University, joan.whipp@marquette.edu

Stephannie Chiarelli

Marquette University, stephanie.chiarelli@marquette.edu

Accepted version. Educational Technology Research and Development, Vol. 52, No. 4 (December 2004): 5-21. DOI. (C) 2004 Springer. Used with permission.

Shareable Link. Provided by the Springer Nature SharedIt content-sharing initiative. 


\title{
Self-Regulation in a Web-Based Course: A Case Study
}

\author{
Joan L. Whipp \\ Department of Educational Policy and Leadership \\ Marquette University \\ Milwaukee, WI \\ Stephannie Chiarelli \\ Department of Educational Policy and Leadership \\ Marquette University \\ Milwaukee, WI
}

Little is known about how successful students in Web-based courses self-regulate their learning. This descriptive case study used a social cognitive model of self-regulated learning (SRL) to investigate how six graduate students used and adapted traditional SRL strategies to complete tasks and cope with challenges in a Web-based technology course; it also explored motivational and environmental influences on strategy use. Primary data sources were three transcribed interviews with each of the students over the course of the semester, a transcribed interview with the course instructor, and the students' reflective journals. Archived course documents, including transcripts of threaded discussions and student Web pages, were secondary data sources. Content analysis of the data indicated that these students used many traditional SRL strategies, but they also adapted planning, organization, environmental structuring, help seeking, monitoring, record keeping, and selfreflection strategies in ways that were unique to the Web-based learning environment. The data also suggested that important motivational influences on SRL strategy use-self-efficacy, goal orientation, interest, and attributions-were shaped largely by student successes in managing the technical and social environment of the course. Important environmental influences on SRL strategy use included instructor support, peer support, and 
course design. Implications for online course instructors and designers, and suggestions for future research are offered.

Many argue that traditional learning experiences do not prepare students for the high degree of self-regulated learning (SRL) and control required in Web-based courses (Brooks, Nolan, \& Gallagher, 2001; Eastmond, 1995; Hartley \& Bendixen, 2001; Hill \& Hannafin, 1997; Loomis, 2000). However, literature on Web-based learning has focused little on how to be a strategic learner in hyperspace (Alexander, Graham, \& Harris, 1998; Dillon \& Gabbard, 1998). Instead, studies have centered on test performance and grades (Arvan, Ory, Bullock, Burnaska, \& Hanson, 1998; Wegner, Holloway, \& Garton, 1999); learner satisfaction (Hiltz, 1997; Richardson \& Swan, 2003; Spooner, Jordan, Algozzine, \& Spooner, 1999); learning styles (Clark, 1999; Neuhauser, 2002); and instructional design that can support SRL (Cennamo \& Ross, 2000; Ley \& Young, 2001; Niemi, Nevgi, \& Virtanen, 2003).

The few studies that do address SRL strategy use in Web-based courses (Eastmond, 1995; Loomis, 2000; Styles \& Zariski, 2000) are limited. In his correlational study of 28 students in an online research methods class, Loomis found that time management skills strongly correlated with final grades and that effective use of study aids was a strong predictor of students' overall performance (final grade, final exam, assignments). The study, however, offers little detail on how, if at all, these strategies differ from those used in face-to-face environments. Similarly, Styles and Zariski interviewed 16 first- and third-year law students about their use of learning strategies in two online courses, as well as their general impressions of learning online. Except for greater use of help seeking to deal with technical problems, strategy use by these students did not differ greatly from that of students in more traditional educational contexts. Furthermore, the authors did not offer any detailed description of strategy use or ground the study in current theories of SRL.

In an older ethnographic study of nine college students in a computer conferencing environment, Eastmond (1995) identified a number of unique challenges faced by learners: technical access, asynchronicity, text-based discussions, multiple conversations, information overload, and isolation. He also described some unique

Educational Technology Research and Development, Vol. 52, No. 4 (2004): pg. 5-21. DOI. This article is (C) Springer and permission has been granted for this version to appear in e-Publications@Marquette. Springer does not grant permission for this article to be further copied/distributed or hosted elsewhere without the express permission from Springer. 
participation, reading, note taking, information processing, and communication strategies that these college students used to cope with those challenges. Although he looked at these strategies within a broader framework of learning-how-to-learn theories in the adult education literature of the 1980s (Smith, 1982, 1990), he concluded that for the most part these learners were not consciously or systematically using strategies in a way that could be called selfdirected. He called for further investigation of how learners can be helped to become more self-aware users of effective learning strategies in this unique environment. Such an investigation, however, needs to be grounded in current literature on SRL.

\section{SRL Models}

Theories and models of self-regulated academic learning emerged in the 1980s in an effort to describe what successful learners do (Bandura, 1986; Boekaerts, Pintrich, \& Zeidner, 2000; Zimmerman, 1989, 2000). Zimmerman (2000) defined self-regulation as "selfgenerated thoughts, feelings, and actions that are planned and cyclically adapted to the attainment of personal goals" (p.14). Most SRL theorists agree that these thoughts, feelings, and actions have interrelated cognitive, affective, motivational, and behavioral dimensions (Zeidner, Boekaerts, \& Pintrich, 2000); however, theorists and models differ on which dimensions they emphasize and, consequently, what strategies and processes they encourage to promote academic success.

Operant models (Kanfer, 1977; Mace, Belfiore, \& Hutchinson, 2001) focus on behavioral dimensions of SRL. Based on the premise that learning and behavior are influenced largely by external stimuli and the consequences immediately following an action, SRL results from the strategic manipulation of external stimuli. Operant models train students to set target behavioral goals that will improve academic achievement (e.g., increased class attendance or increased attentiveness); systematically observe, record, and evaluate progress; and tailor rewards to the degree to which target goals are reached. In these models, self-application of reinforcement strategies allows students to reach their goals.

Educational Technology Research and Development, Vol. 52, No. 4 (2004): pg. 5-21. DOI. This article is (C) Springer and permission has been granted for this version to appear in e-Publications@Marquette. Springer does not grant permission for this article to be further copied/distributed or hosted elsewhere without the express permission from Springer. 
Rooted in information-processing theories, cognitive models of SRL (Corno \& Mandinich, 1983; Winne, 2001; Winne \& Hadwin, 1998) stress use of metacognitive strategies such as self-monitoring and selfevaluation to perform complex academic tasks. In their four-stage model of SRL, for example, Winne and Hadwin (1998) used monitoring to (a) define the task, (b) set goals, (c) plan, and (d) enact strategies to reach those goals. Then, continuous monitoring and evaluation of progress on goal achievement leads to continuous adaptation of metacognition, strategies, and even goals. Cognitive models contrast to operant models in that they focus on covert rather than overt processes. While they pay some attention to motivational influences on whether a learner will employ a particular learning strategy, they do not focus on social or environmental factors that may be influencing metacognition and academic achievement.

Social cognitive models of SRL (Bandura, 1986; Pintrich, 2000; Schunk, 2001; Zimmerman, 1989, 2001) distinguish themselves from strictly cognitive models in that they see the interrelationship among self-generated learning strategies, beliefs (such as efficacy and goal orientation), feelings (performance anxiety, fears), and social and physical environment. Zimmerman $(1998,2000)$ described a threephase cyclical model of self-regulation that includes (a) forethought, (b) performance, and (c) self-reflection. In each of these phases a self-regulated learner combines cognitive strategy use with key motivational beliefs that can be, in turn, influenced by social and environmental factors. For example, in the forethought stage, the successful self-regulated learner combines strategic goal setting and planning with strong self-efficacy beliefs to set realistic goals that, when achieved, lead to greater self-efficacy and willingness to strive for loftier goals. In the performance phase, learners employ various self-control strategies (attention focusing, self-instruction) and selfobservation strategies (self-monitoring and record keeping), along with traditional cognitive strategies (rehearsing, reviewing). Corno (2001) expanded this phase to include control of the task environment (e.g., organizing instructional materials, information-seeking, structuring the study environment) and control of others in the task environment (e.g., seeking help from peers and teacher). Finally, in the self-reflection phase, learners use self-evaluation strategies to judge performance. These judgments hinge greatly on assessment of

Educational Technology Research and Development, Vol. 52, No. 4 (2004): pg. 5-21. DOI. This article is (C) Springer and permission has been granted for this version to appear in e-Publications@Marquette. Springer does not grant permission for this article to be further copied/distributed or hosted elsewhere without the express permission from Springer. 
what caused the results, such as whether poor performance is due to limited ability or insufficient effort. Such judgments, in turn, influence future forethought and performance.

\section{Purposes of the Present Study}

\section{Research Questions}

What does SRL look like in cyberspace? Does previous thinking about SRL hold up in these new learning environments? Because there has been so little research on SRL in Web-based settings, this study was designed to use current thinking about SRL to address these broad questions and surface issues that might warrant further study. We chose Zimmerman's (1986, 1989, 1998, 2000) social cognitive model of SRL as a theoretical framework because recent research on Web-based environments has emphasized the importance of social and environmental factors (Gunawardena \& Zittle, 1997; Hiltz, 1997; Richardson \& Swan, 2003; Rourke, Anderson, Garrison \& Archer, 2001; Swan, 2002, 2003). Zimmerman's model not only offers an outline of key subprocesses for SRL (Zimmerman, 1986, 1989) but also a way to look at the motivational and environmental factors that influence enactment of SRL strategies (Zimmerman, 1998, 2000). With the Zimmerman model in mind, then, our study focused on these questions:

1. How do students use and adapt traditional SRL strategies to complete tasks and cope with challenges in a Web-based course?

2. What motivational influences on SRL strategy use are evident in this course?

3. What environmental influences on SRL strategy use are evident in this course?

\section{Context}

For the past six years, a midsized private university has offered Web-based courses in a master's program for practicing teachers. The first author helped develop this master's program, and has been teaching in it for five years. To reduce potential bias, she conducted the study with the second author, a graduate assistant who was 
studying in another department and had no connection with this program or the students in it.

At the time of the study, 75 students were active in the program. Approximately $65 \%$ taught in a large urban public school district and had fewer than seven years of teaching experience; of those, $10 \%$ taught in elementary schools, and 55\% taught in middle or high schools. Approximately $25 \%$ of the students taught in urban private schools or suburban public schools, and about $10 \%$ taught in postsecondary schools. With an average age of 34 , about $45 \%$ of the students were second-career teachers. Typically, they entered the program with a wide range of technology proficiency and experience; most tended to be new to Web-based learning. When this study was conducted, all Web-based courses were using Lotus Notes/Learning

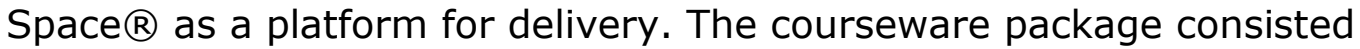
of four databanks: (a) a schedule (which included the course syllabus, assignment details, and course assessment information); (b) a media center (which included a variety of supplementary visual and print resources, Website links, and model assignments); (c) the course room (where all threaded discussions were posted and where students participated in a course bulletin board; and (d) profiles (containing student and instructor personal Web pages and pictures). Conducted primarily online but usually with an initial and concluding face-to-face session, the Web-based courses in this program were designed to be outcome based, performance assessed, and highly interactive with regular, required asynchronous discussions.

The case study reported here took place during the fall of 2000 in a three-credit, 15-week graduate course, "Using Technology for Instruction and Assessment." The course introduced students to a variety of technological tools that can support standards-based instructional and assessment design: presentation managers, interactive electronic mail, multimedia applications, desktop publishing, assistive technologies, animation, and electronic portfolios. Each week, students read assigned articles and completed a short written assignment; most weeks, they also participated in an asynchronous discussion on the readings. Other assignments included an online reflective journal and a major instructional design project.

Educational Technology Research and Development, Vol. 52, No. 4 (2004): pg. 5-21. DOI. This article is (C) Springer and permission has been granted for this version to appear in e-Publications@Marquette. Springer does not grant permission for this article to be further copied/distributed or hosted elsewhere without the express permission from Springer. 


\section{Method}

Because this study was intended to develop a rich picture of student SRL processes in a Web-based course and surface issues that might warrant future attention, we chose a naturalistic and descriptive method of inquiry (Lincoln \& Guba, 1985), using a small group of students and their instructor as informants. The aim was to recruit a sample of six to eight students in the same course who represented the diversity found in our master's program with regard to age, ethnic background, gender, teaching position, and experience with computers and Web-based courses.

\section{Participants}

The first author recruited volunteers at the initial face-to-face session of the course. She explained that the study was an effort to obtain a better understanding of how students learn in Web-based courses so that students can be better supported in them. Volunteers would need to commit to approximately three hours of interviews during the semester and allow the researchers to access online journals and postings, and interview the instructor about their performance. Rights to privacy, confidentiality, and leaving the study at any time were assured. All 15 students in the class were encouraged to volunteer, although it was explained that not all students who volunteered would necessarily be chosen to participate because of the need for a small but representative sample of students. So that the instructor would be unaware of who volunteered, students filled out a brief questionnaire about their technology background and interest in participation. Of the 15 students, 10 volunteered. When contacted by phone to confirm interest, 2 dropped out because of scheduling conflicts. At that point, to achieve a balance in gender, age, ethnic background, teaching, and technology experience, we selected 6 of the remaining 8 volunteers. An e-mail letter was sent to all of the volunteers thanking them for their willingness to participate and explaining the rationale for selection.

Participants included three males and three females ranging in age from 27-53, with a median age of 33 . They came from a variety of

Educational Technology Research and Development, Vol. 52, No. 4 (2004): pg. 5-21. DOI. This article is (C) Springer and permission has been granted for this version to appear in e-Publications@Marquette. Springer does not grant permission for this article to be further copied/distributed or hosted elsewhere without the express permission from Springer. 
racial and ethnic backgrounds: African American, Native American, Puerto Rican, and Caucasian. All were currently teaching in a range of institutions, including urban and suburban, public and private, and middle school, high school, and college; they were teaching English, social studies, math, and Spanish. All except one were taking a Webbased course for the first time, and they reported a range of experiences with technology. Table 1 profiles the six participants.

\section{Data Collection}

Student interviews, an instructor interview, and the students' reflective journals were primary data sources. Archived course documents (course syllabus, assignment descriptions, threaded discussions, course bulletin board, and student Web pages) were secondary data sources.

\section{Student Interviews}

The second author interviewed each of the six students for approximately one hour twice during the semester (third and seventh week) and once during the two weeks after course completion. She conducted these interviews at the primary site where the students worked on the course (home, workplace, or office) in front of the computer they typically used, so that they could show her how they navigated course materials and discussions. In each interview, she asked students to describe how they completed assignments for the previous week, what strategies they used, their challenges, and what supported them. She also asked them to describe their thoughts, feelings, and motivations while learning online, and to evaluate their performance in the course. (A sample of the interview questions is included in the Appendix.) All interviews were taped and transcribed.

\section{Online Journals}

The online journal was a course requirement. Fives times during the semester (1st, 2nd, 6th, 9th, and 11th weeks), prompted with specific topics and questions, students wrote reflections on their online learning experiences. Topics for the journal entries included anticipated challenges, online interaction with peers, applications of

Educational Technology Research and Development, Vol. 52, No. 4 (2004): pg. 5-21. DOI. This article is (C) Springer and permission has been granted for this version to appear in e-Publications@Marquette. Springer does not grant permission for this article to be further copied/distributed or hosted elsewhere without the express permission from Springer. 
NOT THE PUBLISHED VERSION; this is the author's final, peer-reviewed manuscript. The published version may be accessed by following the link in the citation at the bottom of the page.

Web-based learning in middle and high school, and advice to future online learners. The course instructor assessed each journal entry on idea development, evidence of critical thinking, and timeliness.

\section{Instructor Interview}

Two weeks after the course ended and grades were submitted, the instructor of the course was interviewed on what she had observed in self-regulatory strategy use and motivation in each of the six participants. Her hour-long interview was tape recorded, transcribed, and used primarily to triangulate analysis of the student interviews and journals.

\section{Course Documents and Student Postings}

Because most self-regulatory strategy use involves covert rather than overt processes (Zimmerman, 2000, 2001), we were limited in how we could use the course documents and student postings to address our research questions. We used the course syllabus, assignment descriptions, and student Web pages primarily to contextualize the interviews and online journals. To elaborate understanding of student planning and time management strategies, we recorded frequencies of assignment and discussion postings by each student per week, timing of postings, length of messages, and evidence of editing. To elaborate understanding of student helpseeking strategies, we recorded communication patterns (who spoke to whom, and frequency of student-student and student-teacher interactions). Finally, we searched the weekly discussion transcripts for any additional evidence that could confirm or disconfirm our understanding of motivational and environmental influences on SRL strategy use.

\section{Data Analysis and Coding Techniques}

To examine the 18 transcribed student interviews, 30 student journal entries, and 1 instructor interview, we used both individual case and cross-case analytic techniques (Patton, 1990; Stake, 1995; Yin, 1994). We began with a search for patterns within the data on each of the students, and then across all students, using a constant

Educational Technology Research and Development, Vol. 52, No. 4 (2004): pg. 5-21. DOI. This article is (C) Springer and permission has been granted for this version to appear in e-Publications@Marquette. Springer does not grant permission for this article to be further copied/distributed or hosted elsewhere without the express permission from Springer. 
comparative method (Glaser \& Strauss, 1967). After the first round of interviews, we each read the set of student interview transcripts and journal entries several times and separately marked the texts to capture main ideas or domains. We then negotiated agreement on all units for analysis. Using Zimmerman's social cognitive model of selfregulation as a framework (Zimmerman, 1986, 1996, 2000, 2002), we independently made a list of coding categories under the broad categories of our questions and then met to agree on a preliminary list. We independently tried these coding categories on one interview transcript and then came together to reach consensus on coding and to refine coding categories. We continued this process of separate and joint coding and refinement with all of the other interviews and journal entries until we reached $100 \%$ agreement on all units for analysis, coding, and categories.

When all interviews and journals had been coded, we collated the data by both individual student and across students by coding category. From these data we made charts for each student indicating frequencies for strategies used, significant strategy adaptations, motivational beliefs, social supports, and other environmental supports discussed in the interviews and online journals.

Using the same coding categories agreed upon for the student interviews and journals, we coded the transcribed interview of the instructor and used this coded information to refine the charts developed for each student. We then looked for confirming and disconfirming evidence (Stake, 1995) in the instructor interview and discussion transcripts to triangulate data already drawn from the student interviews and journals. Based on this analysis, we expanded the charts on individual students and across students on the various self-regulation strategies and adaptations. For example, one student told us that he often sought help from the instructor, his peers, and a family member throughout the course. Our interview with the instructor, however, indicated that his frequent help seeking was not self-regulatory but highly dependent on others (Karabenick, 1998). Furthermore, the student's participation patterns (most frequently during the final two hours of the deadline date), and the brevity and lack of editing in many of his postings, suggested that this student had difficulty with SRL. We then wrote case reports on strategy use,

Educational Technology Research and Development, Vol. 52, No. 4 (2004): pg. 5-21. DOI. This article is (C) Springer and permission has been granted for this version to appear in e-Publications@Marquette. Springer does not grant permission for this article to be further copied/distributed or hosted elsewhere without the express permission from Springer. 
adaptations, and motivational beliefs for each of the six students. We also wrote cross-case reports on use and adaptations for each of the strategies and motivational beliefs that emerged as significant: planning and time management, self-instruction, organizing and transforming course materials, environmental structuring, selfmonitoring and record keeping, help seeking, self-evaluation, selfefficacy, goal orientation, interest, and attributions for success.

\section{Results}

\section{Use and Adaptation of Traditional SRL Strategies}

While these students displayed some strategies that successful students use in any environment (organizers, schedules, note taking, charts, reducing distractions, help-seeking from the instructor and peers), they demonstrated a number of significant adaptations of SRL strategies to fit their Web-based environment. Using Zimmerman's (1998, 2000) social cognitive framework of forethought, performance, and reflection, we summarize these strategies in Table 2, and then describe each in more detail.

\section{Goal-setting and planning}

According to Zimmerman (1998, 2000), SRL begins in a forethought phase that includes goal setting and strategic planning, implemented largely on the basis of self-efficacy beliefs. In their interviews and journals, all six students mentioned the need for careful time management, and they reported using traditional goal setting and planning aids such as calendars and organizers to plan the timing of course activities and juggle multiple academic, professional, and personal demands. However, students reported some planning strategies that seemed uniquely adapted for a Web-based environment: (a) daily logons; (b) coordination of online and off-line work; and (c) planning for technical problems.

Elizabeth, Marie, and Tom reported the need to be in the course on almost a daily basis "to see what . . . new things are going on," to check out responses to their postings and because, as Elizabeth explained, "it can become easy to become a procrastinator and feel as 
though you have all the time to get things done." Frequencies and dates of individual student postings verified that these students logged into the course at least 4-5 times each week.

Interviews and discussion transcripts also revealed that all of the students developed weekly plans for completing course requirements and coordinating online and off-line work. Some students reported spending time off-line planning what they were going to say. For example, Marie explained, "I felt the need to really think things out before responding [to] really take into consideration all the underlying assumptions." Most allotted the first couple of days of the weekly course modules for checking the course schedule, printing out needed materials, and doing the required readings. Then midweek they posted a response to the week's prompt questions. On the days following, they wrote short responses and questions to other students in the class. Elizabeth reported a fairly rigorous routine, a pattern that was also observed in the discussion transcripts:

I don't do anything on Monday . . . Tuesday I spend probably between twelve and one online reading. Wednesday I do the posting . . .. Thursday and Friday I do online reading and some posting here at school from 11:30 to about 1:00. Saturday morning I do reading and post from home, and Sunday I look it all over.

Dan's interview and posting patterns, in contrast, revealed that most of his routines were conducted off-line and that he viewed the course more as an independent study than as a course where he needed to interact significantly with other students. On Tuesday or Wednesday he printed out the entire module and did the assigned reading off-line, using the discussion prompts to guide his reading. Then, off-line, he composed a written response to the prompt questions, checked it for spelling, grammatical errors, and completeness. Finally, most often on Sunday night, he logged in for about 15-30 min to post what was required for that week.

In their interviews, all six students mentioned the need to plan for inevitable technical problems in a Web-based course-Internet and server delays, computer freezes, error messages, and, in Tina's case, inexperience with computers. These students described a variety of 
planning strategies designed specifically to address these technical problems. Marie and Tom spoke of the need to allot extra time for "negotiating the machinery" and the need to be "committed to the fact that it's going to take more time, especially in the beginning."

Elizabeth and Tina planned for these technical challenges by setting earlier deadlines. As Elizabeth explained, "I sat down with my Franklin Covey organizer and would write down what things were due, but I would hedge on the dates. I would actually write incorrect dates so I would do them earlier." In her journal, Elizabeth also spoke in detail about how, when faced with a slow server, she still managed to use her time efficiently: "I have read course readings, paid bills, read newsgroups, played games on my Game Boy, wrote papers for another class, done my nails, graded papers, and wrote my Christmas cards all while waiting for the next comment to appear."

\section{Organizing and transforming instructional materials}

In the performance phase of the SRL cycle, learners "focus on the task and optimize their performance" (Zimmerman, 1998, p. 3). They do so by initiating some kind of systematic management and rearrangement of their instructional materials to improve learning. All six students described such strategies. In their study of course readings, for example, they took notes, outlined, underlined, highlighted, and wrote in the margins of course texts. These students also devised unique ways to organize and manage reading and writing demands in the Web-based discussions: printing out and marking up course materials and discussion postings, off-line composing and editing of discussion postings, and sorting Web-based discussion threads.

All of the students reported that they printed out the Web-based course readings as well as directions and rubrics for major assignments. Tom and Robert printed out other students' discussion postings for markup or reference while composing their own written responses. In one of his interviews, Robert spoke of the convenience of doing this, particularly if he did not want to respond to another student immediately: "I can make notes on these and send comments back [later]." Tom said he used this strategy "so I don't have to click back and forth as I'm typing."

Educational Technology Research and Development, Vol. 52, No. 4 (2004): pg. 5-21. DOI. This article is (c) Springer and permission has been granted for this version to appear in e-Publications@Marquette. Springer does not grant permission for this article to be further copied/distributed or hosted elsewhere without the express permission from Springer. 
NOT THE PUBLISHED VERSION; this is the author's final, peer-reviewed manuscript. The published version may be accessed by following the link in the citation at the bottom of the page.

All of the students reported that they composed and edited their longer postings off-line and then cut and pasted them into the Webbased discussions. Tina said that she liked working off-line first in a word processing program because that gave her time and space to write and revise; it was "your place for creating" or to try out "a couple ways to respond" to discussion prompts and other student comments. Marie used the cut-and-paste strategy primarily to avoid technical problems: "I would never compose any assignment online-too many bad things could happen."

Marie and Tina also reported doing a lot of their short discussion postings online, but they frequently used the feature in the course where they could go back and edit their work. Tina said she liked to "make sure things were edited because I still have the feeling that it's written word rather than spoken word, so it carries a little more weight . . .. I'm going to be more careful with what I write down because it exists there permanently."

In one of his journal assignments, Tom wrote about how he managed the challenge of sorting and prioritizing approximately 150 student postings per week in the ongoing online discussions. Even though the comments were supposed to be threaded under different topics, those distinct topics were not always clear because students did not always thread comments on the same topic in the same place. Tom used note cards to organize the various discussion threads. In the middle of the week, after students had put in their first postings, he created a separate card for each major strand of discussion. Then each day he would read all new postings, jotting down on the appropriate note card key ideas (and contributors) relating to each strand of discussion; he would also print out key postings relating to each discussion strand and attach them to the note card so that he could more easily make decisions on how and to what strands he himself would respond.

\section{Structuring the learning environment}

Clearly, when courses are offered asynchronously, the term classroom takes on different meanings. Private homes, places of employment, and the university computer lab all served as classrooms

Educational Technology Research and Development, Vol. 52, No. 4 (2004): pg. 5-21. DOI. This article is (C) Springer and permission has been granted for this version to appear in e-Publications@Marquette. Springer does not grant permission for this article to be further copied/distributed or hosted elsewhere without the express permission from Springer. 
for these students. These unconventional settings for class (although not for study) required that students structure and arrange them in ways "to make learning easier" (Zimmerman, 1986, p. 337) both during off-line study times and online work times. Some of these arrangements were what successful students do in any course. Tom, Robert, and Tina set up quiet areas in their homes for their computers. Tom and Tina used background music to sustain attention to tasks and relax themselves while working in the course. Marie, Dan, and Tina mentioned having food or drink available for study breaks. Marie, who used the university computer lab for much of her work, tried to use it at times when there were not a lot of people "talking or working around you and driving you crazy." These students also invented some ways to enhance their online learning environment: finding a fast computer and Internet connection, and creating a psychological place for class.

Concerns about slow computers and the speed of their Internet connection prompted Elizabeth, Marie, and Tom to schedule work in the course at their workplace or the university rather than home. Elizabeth explained: "[It's] far better to do work here [school] where we have a T1 connection than at home where it's a regular dial-up. Here I got finished a lot faster." Marie and Tom gave the same reason for scheduling most of their online work in the university computer lab.

Elizabeth, Robert, and Tina also described how they needed to create psychological space where they felt they were in class on a consistent schedule. Elizabeth explained, "I had a joke at home. I would say, 'Okay, I'm going to school,' and I would go into my office and come out an hour later having done whatever I needed to do." Similarly, Tina spoke about her new rule at home with her kids: "When I'm in my online class, I can't be interrupted."

\section{Help seeking}

In a study of high- and low-achieving 10th graders, Zimmerman and Martinez-Pons found that "high achievers were distinguished particularly by their use of teachers and peers as sources of social support" (1986, p. 625). In their research on study strategies in college students, Karabenick and Knapp (1991) found that students

Educational Technology Research and Development, Vol. 52, No. 4 (2004): pg. 5-21. DOI. This article is (C) Springer and permission has been granted for this version to appear in e-Publications@Marquette. Springer does not grant permission for this article to be further copied/distributed or hosted elsewhere without the express permission from Springer. 
who use a variety of self-regulating learning strategies tend to seek help more frequently than do other students.

As in any course, these students sought help to clarify expectations on assignments, check on progress, collaborate with others on assignments, and get feedback on writing drafts. All but Elizabeth relied heavily on both online and off-line interactions with the course instructor, and all reported making use of peers or family members in fairly traditional ways. They used e-mail, phone calls, and face-to-face contact for clarification on assignment directions and feedback on assignment drafts. Dan, Tom, Robert, and Tina mentioned the frequent and timely feedback they received from the course instructor as a key factor in their success; the course instructor affirmed that help seeking was an important strategy for most of the students in the course.

These students did report, however, use of help seeking in ways and for reasons unique to the Web-based environment:

- Accessing timely technical expertise.

- Contacting peers to reduce loneliness.

- Using Web-based "helpers."

- Using student postings as models.

All six students reported making quick phone calls or sending emails to the course instructor or a person with technical expertise for help on technical problems. Elizabeth mentioned her father who "is director of technology for a school district"; Dan relied on his wife, "an Information Systems major"; Robert reported that he frequently phoned a "real computer literate" friend. Occasionally, students offered each other technical assistance within the course. For example, early in the course a student mentioned in one of the discussions that she did not know how to cut and paste her discussion comments from a word-processing program into the discussions; Elizabeth quickly responded with detailed step-by-step directions.

In addition to asking for technical help, several students reported the need to use others to keep motivated. Robert explained:

Educational Technology Research and Development, Vol. 52, No. 4 (2004): pg. 5-21. DOI. This article is (C) Springer and permission has been granted for this version to appear in e-Publications@Marquette. Springer does not grant permission for this article to be further copied/distributed or hosted elsewhere without the express permission from Springer. 
Sometimes when you're sitting in that room and you can't find something [or] you don't have enough ideas, you kind of get down on yourself because you're supposed to be self-sufficient . ... If you keep that mentality, I think you would break.

To reduce their loneliness, Robert, Tina, and Tom spoke of seeking connections with classmates in other face-to-face classes, on the telephone, or on the course's informal bulletin board. Tina spoke of how the Web-based experience became much better for her when she stopped treating the course like an independent study and began accessing the help of peers. She found it comforting to know "that somebody's going through the same experience that you're going through ... . [that] they're having difficulty putting together a project or plan as you are."

Not all sources of help were human. As Karabenick (1998) argued, "Increasingly sophisticated and artificial assistance may force us to reconsider the definition of help seeking as necessarily including social agency" (p.219). All of these students sought help from nonhuman, Web-based helpers. Marie and Tom used the Internet to clarify certain concepts or terms that they encountered in their course readings. To get help for some technical problems with the courseware package, Tina used an online technical how-to manual. Robert found the model assignments, available in the online course media center, helpful when he was trying to develop an idea for a major project.

An interesting variation of this Web-based help seeking was evident in reports by Marie, Robert, and Tina on how they used other students' online discussions and submissions to plan and shape their own work. Taking advantage of the running record of what other students were doing in the course, these students were able constantly to compare their own work or planned work in progress to that of others. In a Web-based environment, this form of help seeking can take place without the help givers even knowing that they were giving help (Bell, Greer, McCalla, \& Kettel, 2001). For example, Marie reported that to prepare her own online discussion contributions she often checked them to "see what everybody else [was] gearing their answers toward, so I feel like I'm in synch." Robert humorously referred to this "peeking" at what others were doing as a type of

Educational Technology Research and Development, Vol. 52, No. 4 (2004): pg. 5-21. DOI. This article is (C) Springer and permission has been granted for this version to appear in e-Publications@Marquette. Springer does not grant permission for this article to be further copied/distributed or hosted elsewhere without the express permission from Springer. 
NOT THE PUBLISHED VERSION; this is the author's final, peer-reviewed manuscript. The published version may be accessed by following the link in the citation at the bottom of the page.

cheating: "I got a lot of ideas that I kind of stole from other people. I would . . . use some of those ideas . . . in my own assignments."

\section{Self-monitoring and record keeping}

Zimmerman (1986) defined monitoring as "student-initiated efforts to record events or results" (p. 337). All six students reported traditional monitoring and record-keeping strategies. They regularly calculated their grades, and kept paper and electronic records of completed assignments. Students did report some variations of these traditional strategies, however: backing up discussion postings in multiple ways, monitoring reading and writing for online discussions, and frequently checking the online grade book.

All six students reported taking extra caution in this technical environment when completing and submitting discussion assignments. Elizabeth, Marie, and Robert found it helpful to keep backups of their postings in multiple ways. Marie advised future online students to "save all submissions on [a] computer and on a disc." Tom explained, "I know it's kind of anal, but if sometime it comes up later on that you didn't turn one [discussion assignment] in, I'd say, 'Well, here it is, and this is the date." Dan and Robert said that after submitting a posting, they always went back to "check and see if it made it" into the threaded discussion because sometimes postings appeared in the wrong place.

In addition to monitoring the technical aspects of submitting discussion postings, students also reported ways they monitored their academic progress. Marie was in the course almost daily to check the number of her own discussion comments in comparison with "how many comments everybody [else was] writing." Tom also reported monitoring the postings of other students four to five times a week "by date" (an option available in Lotus Notes) to "keep track of what I've read and what I haven't read." Because the course had a built-in grade book where students could frequently check their grades online, all six students reported doing so at varying frequencies (from daily to every two weeks) rather than keeping paper records of their grades.

Educational Technology Research and Development, Vol. 52, No. 4 (2004): pg. 5-21. DOI. This article is (C) Springer and permission has been granted for this version to appear in e-Publications@Marquette. Springer does not grant permission for this article to be further copied/distributed or hosted elsewhere without the express permission from Springer 
NOT THE PUBLISHED VERSION; this is the author's final, peer-reviewed manuscript. The published version may be accessed by following the link in the citation at the bottom of the page.

\section{Self-reflection}

Bandura (1986) divided the self-reflection phase of SRL into two closely related processes: (a) self-judgment and (b) self-reactions. Self-judgment "involves self-evaluating one's performance and attributing causal significance to the results" (Zimmerman, 2000, p. 21). Self-reactions include level of satisfaction and inferences made about how one needs to alter SRL strategies in future efforts to learn or perform.

All six students reported using traditional self-reflection strategies such as use of assignment criteria checklists and rubrics to make judgments about their performance in course assignments, and use of instructor feedback and grades to gauge progress in the course. For some, however, the Web-based environment seemed to encourage unique self-reflection strategies: using peer feedback to assess performance, and using an audience of peers to shape discussion postings.

Contrary to face-to-face courses, where students rarely receive feedback on their academic work from their peers, Web-based courses can provide students with frequent reactions from classmates in the asynchronous discussions. Several students commented on how they used the continuous feedback of their peers to make judgments about the quality of their own work. "You get so much feedback about your writing," according to Tom. This continual feedback helps "you understand that you're on the right page." Robert evaluated his effectiveness in the course discussions by the number of comments he received. In one interview, he proudly pointed to four comments threaded under his most recent posting: "It just makes you feel good like you gave something substantive to [the discussion]."

The constant presence of an audience of peers in the Web-based environment also seemed to add incentive for continuous selfevaluation of discussion postings. Elizabeth, Tom, and Tina explained how they took special care to reread and edit their written entries in the discussions so that others would want to read them. Tom explained, "Huge, massive paragraphs are intimidating . . ... I tend not to want to read that kind of writing." 
NOT THE PUBLISHED VERSION; this is the author's final, peer-reviewed manuscript. The published version may be accessed by following the link in the citation at the bottom of the page.

\section{Motivational Influences on SRL Strategy Use}

According to Zimmerman's model of self-regulation (2000), various motivational beliefs underlie each phase of the self-regulatory process. In forethought, goal setting and strategic planning are influenced by self-efficacy, goal orientation, and intrinsic interest in the activity. Self-efficacy continues to influence use of self-control and self-observation strategies in the performance stage. Finally, causal attributions, one's level of self-satisfaction, and continued self-efficacy influence self-evaluation and future academic pursuits. In this course, the data indicated that these beliefs were shaped largely by student successes in managing both the technical and social environment of the course.

\section{Self-efficacy}

Social cognitive models of SRL suggest that individual enactment of SRL behaviors in all phases of the learning process depends greatly on one's self-efficacy beliefs. Students who consistently use SRL strategies believe that they are "competent, efficacious, and autonomous" (Zimmerman, 1986; Zimmerman \& Martinez-Pons, 1990). Studies of self-efficacy (Bandura, 1986, 1997; Zimmerman \& Martinez-Pons, 1990) suggest that such beliefs are largely developed in a supportive learning climate where learners are able to observe others successfully using SRL strategies, get helpful feedback on their own strategy use, and experience success with particular learning tasks.

In early interviews and journal entries, all six students discussed their varying degrees of anxiety about learning online. They worried about potential procrastination (Elizabeth), being misunderstood (Dan), missing social contact and interaction (Robert and Tina), their technical expertise (Tina, Tom, and Marie), and their writing skills (Dan). Robert and Tina, in particular, doubted whether they could be as successful in a Web-based course as they were in face-to-face courses. By the end of the course, however, all six said they experienced success in this environment and that they would consider taking another Web-based course. Early access to technical support

Educational Technology Research and Development, Vol. 52, No. 4 (2004): pg. 5-21. DOI. This article is (c) Springer and permission has been granted for this version to appear in e-Publications@Marquette. Springer does not grant permission for this article to be further copied/distributed or hosted elsewhere without the express permission from Springer. 
and early successes with the technical demands of the course seemed to alleviate anxiety and develop a sense of accomplishment. As Tina explained, "At first I perceived obstacles to completing the class . . .. As I got used to the technology, I felt that I could be a much more competent student." And with that competence she "became less dependent" on some of her classmates who had offered her early technical support. By the end of the course, these students demonstrated that they had developed not only a sense of humor about inevitable "technical glitches," but also confidence in troubleshooting their own technical problems. As Robert reflected, "Now, I'm just comfortable with my errors."

\section{Goal orientation}

Studies by Zimmerman and others suggest that students who are more self-regulated tend to "focus on learning progress rather than competitive outcomes" (Zimmerman, 1998, p. 3); they focus on mastery rather than performance goals (Ames, 1992). Such a small sample of students makes it impossible to draw firm conclusions about the influence of goals on SRL strategy use in the course. However, in interviews, both Elizabeth and Robert, who achieved the highest point totals in the course, expressed goals in the course that sounded both performance and mastery oriented. Elizabeth admitted that she was "compulsive" about being "the first person to post" in the discussions and getting a good grade (performance goals), but she also said she wanted to develop projects that would be effective with her students (mastery goal); she was particularly pleased with a lesson that she had designed on teaching Power Point $®$ because "it worked" and her students had enjoyed it. Robert said "I want to get a raise" [and] "I want to get a Master's degree" (performance goals), but he also said he was motivated by a "driving force" to "do my best," to "be a better teacher for my students," and "my love of education" (mastery goals).

\section{Interest}

For all of the students, the course discussions and interaction seemed to influence motivation. During the last three weeks of the course, when the instructor stopped the discussions so that students had more time to complete final assignments, Tom, Marie, Robert, and

Educational Technology Research and Development, Vol. 52, No. 4 (2004): pg. 5-21. DOI. This article is (C) Springer and permission has been granted for this version to appear in e-Publications@Marquette. Springer does not grant permission for this article to be further copied/distributed or hosted elsewhere without the express permission from Springer. 
Tina said that their interest in the course waned. They no longer had a strong reason each day to go into the course and see what was happening in the discussions or how many people had responded to their comments: "I depended on the interaction with other students to keep myself motivated, and when that wasn't there, my motivation dropped a lot," reported Tina.

\section{Attributions}

Part of the self-reflection stage involves making judgments about the "causal meaning of the results, such as whether poor performance is due to one's limited ability or to insufficient effort" (Weiner, 1979). Such attributions are important because they determine whether learners feel empowered to adapt learning strategies for a better outcome in the future or are inclined to give up. Although our interviews were not designed to address student attributions specifically, they suggest that the students whom the instructor viewed as the strongest in the class (Elizabeth and Robert) were those who placed the primary reason for success on their own efforts. Elizabeth was convinced that her strategies of time management and planning prevented her from procrastination and contributed greatly to her success. Robert also attributed success in the course to the various routines that he developed for planning, writing, time management, and dealing with technical problems.

\section{Environmental Influences on SRL}

\section{Support from the instructor}

Five of the six students mentioned the importance of helpful and positive feedback from the instructor. Tom reported: "She's really good at pinpointing things that come out of your work." He was so inspired by her praise that he saved hard copies of her comments. She "was really helpful online, encouraging us to do the right thing," according to Robert. Tina praised her "amazing ability to raise questions that caused me to really examine my ideas as well as the concepts and theories that we have been studying." They also appreciated that "she [was] very accessible" by e-mail or phone. The course discussion transcripts substantiate these student claims. The

Educational Technology Research and Development, Vol. 52, No. 4 (2004): pg. 5-21. DOI. This article is (C) Springer and permission has been granted for this version to appear in e-Publications@Marquette. Springer does not grant permission for this article to be further copied/distributed or hosted elsewhere without the express permission from Springer. 
instructor was a constant presence in the discussions with postings to individual and groups of students 4- 5 days in each week of the 15week semester. Her postings included frequent supportive comments ("Thanks for taking the time to answer my questions and for your comprehensive responses. Your students are fortunate to have a teacher like you"). She also often posed challenging questions ("Do you think that it is possible to create a constructivist Spanish class? Do you see yourself as a constructivist teacher? Do you see any problems with the way you assess your students?").

\section{Peer support}

The course transcript and student interviews suggested a high level of peer support in this course. Marie, Tina, and Robert indicated that they went into the course "uncertain about establishing a positive comfort level with . . . peers." Marie described them "as faceless names on the screen." She added, "You feel you are talking to ghosts." In a discussion posting, Tina wrote about the difficulty of carrying "on discussion when you cannot see the reaction of others because so much of communication is in the face, gesture, and body reactions of both the speaker and the listener." Despite such misgivings, these students said they were pleasantly surprised at the high level of helpful interaction with peers in the course where, according to Marie, "you could say something and others would answer and ask you questions" and where "you feel on the same level as everybody else." Robert, who described himself as "traditional" because he enjoys being with others in a classroom, became more convinced of his ability to be successful in the Web-based environment because of the helpful and challenging responses that he got from peers in the discussions: "Their many perspectives on issues really challenged my thinking; I didn't think that would be possible in this type of learning environment."

\section{Course design}

Elements in the design of the course seemed to encourage students to use specific SRL strategies. Elizabeth, Marie, Tom, and Robert mentioned that the Web-based course schedule and assignment handouts made planning and time management easier. All of the students spoke about the ease of regular self-monitoring of

Educational Technology Research and Development, Vol. 52, No. 4 (2004): pg. 5-21. DOI. This article is (C) Springer and permission has been granted for this version to appear in e-Publications@Marquette. Springer does not grant permission for this article to be further copied/distributed or hosted elsewhere without the express permission from Springer. 
progress through the online grade book. Tom, Tina, and Marie indicated that the availability of model assignments, supplementary articles and resources, and 24-hour access to the instructor and peers made help more accessible than in some face-to-face courses. As Tom explained, "When I have questions about anything, I feel like I can get answers." Marie and Dan used the online assignment rubrics, spell check, and grammar check to evaluate and edit their writing assignments.

\section{Discussion and Implications}

Although limited by the number of students studied and by the fact that they were graduate students who arguably might be more adept at self-regulating their learning, this case study, using a social cognitive framework, uncovered a number of planning, organizing, self-monitoring, environmental-structuring, help seeking, and reflection strategies that could be useful to learners in Web-based environments. Online instructors should consider sharing these strategies with their students. Course designers might consider including more tools and study aids in Web-based courses that aim specifically at assisting and encouraging students to use SRL strategies. (For examples, see Cennamo \& Ross, 2000; Niemi et al., 2003).

This case study also surfaced important topics and questions for further research on SRL in Web-based environments:

- SRL strategy use and achievement in varied Web-based task environments.

- Help seeking and help giving among peers in Web-based environments.

- Self-efficacy, goal orientation and interest impacts in Web-based environments.

- Influences of self-evaluation and attributions on SRL in Webbased courses over time.

- Models for SRL in Web-based environments.

Educational Technology Research and Development, Vol. 52, No. 4 (2004): pg. 5-21. DOI. This article is (C) Springer and permission has been granted for this version to appear in e-Publications@Marquette. Springer does not grant permission for this article to be further copied/distributed or hosted elsewhere without the express permission from Springer. 


\section{SRL Strategy Use and Achievement in Varied Web- based TaskEnvironments}

In this study, we looked at SRL in a graduate, project-based course emphasizing critical analysis and evaluation of instructional technology. On the other hand, Cennamo and Ross (2000) studied SRL in a large undergraduate lecture course aiming at developing introductory knowledge and understanding of psychology and using multiple-choice exams for assessment. Whereas students in the undergraduate course self-evaluated and monitored their study for exams through practice quizzes, the graduate students in this case study self-evaluated and monitored their work by using course rubrics and comparing their work to that of other students in the class. Unlike the undergraduate students, who needed to prepare for four exams, the graduate students, who took no exams, did not use rehearsal or memory strategies or spend time reviewing for tests. On the other hand, the graduate students appeared to use more help-seeking strategies than did the undergraduates. Among the graduate students in this case study, however, there seemed to be varying levels of autonomous and dependent help seeking (Karabenick, 1998). How do varied task environments in Web-based courses, including different goal and reward structures or different levels of support, affect both SRL strategy use and achievement? How might outcomes be affected by developmental levels, particularly levels of self-regulation? Experimental studies with larger groups of students are needed to address these questions.

\section{Help Seeking and Help Giving Among Peers in Web- based Environments}

Current views of learning suggest that social assistance is not an option, but is critical to the learning process (Salomon \& Perkins, 1998; Vygotsky, 1978). Although our study suggested that students valued their helpful interactions with the instructor, observations of the discussions suggest that some students limited their help seeking and social interactions to peers in the course most like themselves (e.g., same gender, same race, similar work setting) while ignoring others. The results also revealed some interesting variations of traditional help

Educational Technology Research and Development, Vol. 52, No. 4 (2004): pg. 5-21. DOI. This article is (C) Springer and permission has been granted for this version to appear in e-Publications@Marquette. Springer does not grant permission for this article to be further copied/distributed or hosted elsewhere without the express permission from Springer. 
seeking and peer assistance in the Web-based course, including the use of peer postings as models, and direct contact with peers to reduce loneliness. Larger scale studies of the interaction patterns of students in Web-based courses are needed to more fully explore these findings. How do students use peer assistance in Web-based courses? To what extent and how are students in Web-based courses able to help each other learn? What instructional strategies or course structures encourage broader interactions, help seeking, and help giving among students in Web-based courses?

\section{Self-Efficacy, Goal Orientation and Interest Impacts on $S R L$ in Web-based Environments}

This study suggested that many new online learners begin with uncertainties about their ability to manage the technical, organizational, and social challenges in a Web-based environment. Early successes, encouragement from the instructor, and modeling seemed to help students feel more confident and efficacious in their ability to learn online. The results also hinted that individual goal orientation and interests were mediating SRL strategy use, but the study was not designed to probe deeply into these motivational processes. A more focused investigation of how such motivational beliefs operate and exert influence on learning in Web-based environments with a larger sample of online learners at varying levels of motivation could significantly enhance understanding of SRL in Webbased environments.

\section{Influences of Self-Evaluation and Attributions on SRL in Web-based Courses over Time}

In interviews and final journal entries, all of the students in this small sample said that they felt successful at the end of the course. However, their attributions for success varied. Robert, Elizabeth, and Marie put emphasis on their effort and persistence. Tina, Dan, and Tom stressed that the social support available to them contributed greatly to their success. Elizabeth and Dan said that their technical expertise made learning online easier. How do such reactions and attributions influence subsequent SRL strategy use in Web-based

Educational Technology Research and Development, Vol. 52, No. 4 (2004): pg. 5-21. DOI. This article is (C) Springer and permission has been granted for this version to appear in e-Publications@Marquette. Springer does not grant permission for this article to be further copied/distributed or hosted elsewhere without the express permission from Springer. 
courses? Did these learners use and adapt the SRL strategies that they devised in this course in subsequent courses? If so, in what ways? What about students who do not feel as successful at the end of an online course? Longitudinal studies of SRL strategy use and achievement in Web-based courses with a more focused look at the role of self-reactions and attributions are needed to address these questions.

\section{More Robust Models for SRL in Web-based Environments}

Our findings suggest that social cognitive models can be helpful in thinking about SRL in Web-based environments, particularly because they address important motivational beliefs such as selfefficacy and goal orientation. They also suggest that SRL is context dependent, that the unique features of a learning environment may influence whether or not a learner enacts SRL strategies. Social cognitive models also acknowledge the importance of instructors and peers in the learning environment, an importance underscored by this study and substantiated by other studies (Gunawardena \& Zittle, 1997; Richardson \& Swan, 2003; Rourke et al., 2001; Swan, 2002, 2003).

Most social cognitive models, however, focus on individual learning processes. They do not fully account for collective or distributed learning processes that are often encouraged in Web-based courses, including the one described here. Unlike traditional courses, where it is possible to function primarily as an individual learner and only minimally interact with other students in the class, this course required that students interact with other students in the discussions at least three times per week. One third of the course grade was based on the quality of participation and interactions; students who failed to enter these discussions in the first few weeks of the course were dropped. What unique social and communication strategies are needed to manage the complex environment of a Web-based course? Larger-scale studies of the group-learning processes in Web-based environments are needed so that more robust and predictive models of SRL that include individual and collective SRL processes can be considered and developed. In the

Educational Technology Research and Development, Vol. 52, No. 4 (2004): pg. 5-21. DOI. This article is (C) Springer and permission has been granted for this version to appear in e-Publications@Marquette. Springer does not grant permission for this article to be further copied/distributed or hosted elsewhere without the express permission from Springer. 
current rush to put courses online, often the voices and needs of learners are overlooked. Using a social cognitive framework, this study was an initial step in much-needed investigation of the processes that successful students use to plan, organize, monitor, and evaluate their work in Web-based environments and to manage unique motivational and social demands. We hope that more studies will follow that can help learners become more self-directed and academically successful in these new places to learn.

\section{References}

Alexander, P. A., Graham, S., \& Harris, K. R. (1998). A perspective on strategy research: Progress and prospectus. Educational Psychology Review, 10(2), 129-154.

Ames, C. (1992). Achievement goals and the classroom motivational climate. In D. H. Schunk \& J. L. Meece (Eds.), Student perceptions in the classroom (pp. 327-348). Hillsdale, NJ: Erlbaum.

Arvan, I., Ory, J. C., Bullock, C. D., Burnaska, K. K., \& Hanson, M. (1998). The SCALE efficiency projects. Journal of Asynchronous Learning Networks, 2(2). Retrieved February 21, 2004 from http://www .alnresearch.org/Data_Files/articles/full_text/arv an2.htm.

Bandura, A. (1986). Social foundations of thought and action: A social cognitive theory. Englewood Cliffs, NJ: Prentice Hall.

Bandura, A. (1997). Self-efficacy: The exercise of control. New York: W. H. Freeman.

Bell, S., Greer, J., McCalla, G., \& Kettel, L. (May, 2001). Help-seeking in an asynchronous help forum. In R. Luckin (Ed.), Proceedings of workshop on help provision and help seeking in interactive learning environments. International Conference on Artificial Intelligence in Education, San Antonio. Retrieved February 21, 2004 from http://www.cogs.susx.ac.uk/users /bend/aied2001/bull.pdf.

Boekaerts, M., Pintrich, P. R., \& Zeidner, M. (Eds.). (2000). Self-regulation: Theory, research, and applications. Orlando, FL: Academic Press.

Brooks, D. W., Nolan, D. E., \& Gallagher, S. M. (2001). Web-teaching: A guide to designing interactive teaching for the World Wide Web (2nd ed.). New York: Kluwer Academic/Plenum Publishers.

Cennamo, K. S., \& Ross, J. D. (2000). Strategies to support self-directed learning in a Web-based course. Paper presented at the annual meeting of the American Educational Research Association, New Orleans.

Clark, D. (1999). Getting results with distance education. The American Journal of Distance Education, 12(1), 38-51.

Educational Technology Research and Development, Vol. 52, No. 4 (2004): pg. 5-21. DOI. This article is (C) Springer and permission has been granted for this version to appear in e-Publications@Marquette. Springer does not grant permission for this article to be further copied/distributed or hosted elsewhere without the express permission from Springer. 
NOT THE PUBLISHED VERSION; this is the author's final, peer-reviewed manuscript. The published version may be

accessed by following the link in the citation at the bottom of the page.

Corno, L. (2001). Volitional aspects of self-regulated learning. In B. J. Zimmerman \& D. H. Schunk (Eds.), Self-regulated learning and academic achievement (pp. 191-225). Mahwah, NJ: Erlbaum.

Corno, L., \& Mandinich, E. B. (1983). The role of cognitive engagement in classroom learning and motivation. Educational Psychologist, 18, 88108.

Dillon, A., \& Gabbard, R. (1998). Hypermedia as an educational technology: A review of the quantitative research literature on learner comprehension, control, and style. Review of Educational Research, 68(3), 322-349.

Eastmond, D. V. (1995). Alone but together: Adult distance study through computer conferencing. Creskill, NJ: Hampton.

Glaser, B. G., \& Strauss, A. L. (1967). Discovery of grounded theory: Strategies for qualitative research. Chicago: Aldine.

Gunawardena, C. N., \& Zittle, F. J (1997). Social presence as a predictor of satisfaction within a computer-mediated conferencing environment. The American Journal of Distance Education, 11(3), 8-26.

Hartley, K., \& Bendixen, L. D. (2001). Educational research in the Internet age: Examining the role of individual characteristics. Educational Researcher, 30(9), 22-26.

Hill, J. R., \& Hannafin, M. J.(1997). Cognitive strategies and learning from the World Wide Web. Educational Technology, Research and Development, 45(4), 37-64.

Hiltz, S. R. (1997). Impacts of college-level courses via asynchronous learning networks: Some preliminary results. Journal of Asynchronous Learning Networks, 2. Retrieved February 21, 2004 at http://www.aln.org /publications/jaln/v1n2/pdf/v1n2_hiltz.pdf.

Kanfer, F. H.(1977). The many faces of self-control, or behavior modification changes its focus. In R. B. Stuart (Ed.), Behavioral self-management: Strategies, techniques, and outcomes (pp. 1-48). New York: Brunner/Mazel.

Karabenick, S. A. (1998). Strategic help seeking: Implications for teaching and learning. Mahwah, NJ: Erlbaum.

Karabenick, S. A., \& Knapp, J. R. (1991). Relationship of academic help seeking to the use of learning strategies and other instrumental achievement behavior in college students. Journal of Educational Psychology, 83, 221-230.

Ley, K., \& Young, D. (2001). Instructional principles for self-regulated learning. Educational Technology Research and Development, 49(2), 93-102.

Lincoln, E., \& Guba, E. (1985). Naturalistic inquiry. Newbury, CA: Sage. Loomis, K. D. (2000). Learning styles and asynchronous learning: Comparing the LASSI model to class performance. Journal of

Educational Technology Research and Development, Vol. 52, No. 4 (2004): pg. 5-21. DOI. This article is (C) Springer and permission has been granted for this version to appear in e-Publications@Marquette. Springer does not grant permission for this article to be further copied/distributed or hosted elsewhere without the express permission from Springer. 
NOT THE PUBLISHED VERSION; this is the author's final, peer-reviewed manuscript. The published version may be accessed by following the link in the citation at the bottom of the page.

Asynchronous Learning Networks, 4(1), 23-31. Retrieved February 21, 2004 at http://www.aln.org/publications/jaln/v4n1/pdf/v4n1_loomis.pdf.

Mace, F. C., Belfiore, P. J., \& Hutchinson, J. M. (2001). Operant theory and research on self-regulation. In B.J. Zimmerman \& D. H. Schunk (Eds.), Self-regulated learning and academic achievement (2nd ed,) (pp.3965). Mahwah, NJ: Erlbaum.

Neuhauser, C. (2002). Learning style and effectiveness of online and face-toface instruction. The American Journal of Distance Education, 16(2), 99-113.

Niemi, H., Nevgi, A., \& Virtanen, P. (2003). Towards self-regulation in Webbased learning. Paper presented at the annual meeting of the American Educational Research Association.

Patton, M. A. (1990). Qualitative evaluation and research methods (2nd ed.). Newbury Park, CA: Sage.

Pintrich. P. R. (2000). The role of goal orientation in self-regulated learning. In M. Boekaerts, P. R. Pintrich, \& Moshe Zeidner (Eds.), Handbook of self-regulation (pp. 451-502). New York: Academic Press.

Richardson, J., \& Swan, K. (2003). Examining social presence in online courses in relation to students' perceived learning and satisfaction, Journal of Asychronous Learning Networks, 7(1), 68-88.

Rourke, L., Anderson, T., Garrison, D. R., \& Archer, W. (2001). Assessing social presence in asynchronous text-based computer conferencing. Journal of Distance Education, 14(2), 50-71.

Salomon, G., \& Perkins, D. N. (1998). Individual and social aspects of learning. In P.D. Pearson \& Iran-Nejad (Eds). Review of research in education, 23 (pp.1-24). Washington, DC: AERA.

Schunk, D. H. (2001). Social cognitive theory and self-regulated learning. In B. J. Zimmerman \& D. H. Schunk (Eds.), Self-regulated learning and academic achievement (2nd ed.) (pp. 125-151). Mahwah, NJ: Erlbaum.

Smith, R. M. (1982). Learning how to learn. Chicago: Follett.

Smith, R. M. (1990). The promise of learning to learn. In R.M. Smith \& Associates (Eds.), Learning to learn across the life span (pp. 3-29). San Francisco: Jossey-Bass.

Spooner, F., Jordan, L., Algozzine, B., \& Spooner, M. (1999). Student ratings of instruction in distance learning and on-campus classes, The Journal of Educational Research, 92, 132-140.

Stake, R. E. (1995) The art of case study research. Thousand Oaks, CA: Sage.

Styles, I., \& Zariski, A. (2000). Enhancing student strategies for online learning. In A. Herrmann \& M. M. Kulski (Eds.), Flexible futures in

Educational Technology Research and Development, Vol. 52, No. 4 (2004): pg. 5-21. DOI. This article is (C) Springer and permission has been granted for this version to appear in e-Publications@Marquette. Springer does not grant permission for this article to be further copied/distributed or hosted elsewhere without the express permission from Springer 
NOT THE PUBLISHED VERSION; this is the author's final, peer-reviewed manuscript. The published version may be accessed by following the link in the citation at the bottom of the page.

tertiary teaching. Proceedings of the 9th Annual Teaching Learning Forum. Perth: Curtin University of Technology.

Swan, K. (2002). Immediacy, social presence, and asynchronous discussion. In J. Bourne \& J. C. Moore (Eds.), Elements of quality online education (Vol. 3). Olin \& Babson Colleges: Sloan Center for Online Education.

Swan, K. (2003). Developing social presence in online course discussions. In S. Naidu (Ed.), Learning and teaching with technology: Principles and practices ( pp. 147-164). London: Kogan Page.

Vygotsky, L. (1978). Mind in society: The development of higher psychological processes. Cambridge, MA: Harvard University Press.

Wegner, S. H., Holloway, K. C., \& Garton, E. M. (1999). The effects of Internet-based instruction on student learning. Journal of Asychncronous Learning Networks, 3(2). Retrieved February 21, 2004 at http://www .aln.org/publications/jaln/v3n2/pdf/v3n2_wegn er.pdf.

Weiner, B. (1979). A theory of motivation for some classroom experiences. Journal of Educational Psychology, 71, 3-25.

Winne, P. H. (2001). Self-regulated learning viewed from models of information processing. In B. J. Zimmerman \& D. H. Schunk (Eds.), Self-regulated learning and academic achievement: Theoretical perspectives (pp. 153-189). Mahwah, NJ: Erlbaum.

Winne, P. H., \& Hadwin, A. F. (1998). Studying as self-regulated learning. In D. J. Hacker, J. Dunlosky, \& A. C. Graesser (Eds.), Metacognition in educational theory and practice (pp. 277-304). Hillsdale, NJ: Erlbaum.

Yin, R. K. (1994). Case study research, design and methods (2nd ed.). Newbury Park, Ca: Sage.

Zeidner, M., Boekaerts, M., \& Pintrich, P. R. (2000). Self-regulation: Directions and challenges for future research. In M. Boekaerts, P. R. Pintrich, \& Moshe Zeidner (Eds.), Handbooik of self-regulation (pp. 749- 768). New York: Academic Press.

Zimmerman, B. J. (1986). Becoming a self-regulated learner: What are the key subprocesses? Contemporary Educational Psychology, 16, 307313.

Zimmerman, B. J. (1989). Models of self-regulated learning and academic achievement. In B. J. Zimmerman and D. H. Schunk (Eds.) Selfregulated learning and academic achievement: Theory, research and practice (p. 1-25). New York: Springer-Verlag.

Zimmerman, B. J. (1996). Developing self-regulated learners: Beyond achievement to self-efficacy. The City University of New York: APA, Washington, D.C.

Zimmerman, B. J. (1998). Developing self-fulfilling cycles of academic regulation: An analysis of exemplary instructional models. In D. H. Schunk \& B.J. Zimmerman(Eds.), Self-regulated learning: From teaching to self-reflective practice (pp. 1-19). New York: Guilford.

Educational Technology Research and Development, Vol. 52, No. 4 (2004): pg. 5-21. DOI. This article is (c) Springer and permission has been granted for this version to appear in e-Publications@Marquette. Springer does not grant permission for this article to be further copied/distributed or hosted elsewhere without the express permission from Springer. 
NOT THE PUBLISHED VERSION; this is the author's final, peer-reviewed manuscript. The published version may be accessed by following the link in the citation at the bottom of the page.

Zimmerman, B. J. (2000). Attaining self-regulation: A social cognitive perspective. In M. Boekaerts, P. R. Pintrich, \& Moshe Zeidner (Eds.), Handbook of self-regulation (pp. 13-39). New York: Academic Press.

Zimmerman, B. J. (2001). Theories of self-regulated learning and academic achievement: An overview and analysis. In B. J. Zimmerman \& D. H. Schunk (Eds.), Self-regulated learning and academic achievement: Theoretical perspectives (pp. 1-37). Mahwah, NJ: Erlbaum.

Zimmerman, B. J. (2002). Achieving academic excellence: A self-regulatory perspective. In M. Ferrari (Ed). The pursuit of excellence through education (pp. 85-110) Mahwah, NJ: Erlbaum.

Zimmerman, B. J., \& Martinez-Pons, M. (1986). Development of a structured interview assessing students' use of self-regulated learning strategies. American Educational Research Journal, 23, 614-628.

Zimmerman, B. J., \& Martinez-Pons, M. (1990). Student differences in selfregulated learning: Relating grade, sex, and giftedness to self-efficacy and strategy use. Journal of Educational Psychology, 82, 51-59. 
NOT THE PUBLISHED VERSION; this is the author's final, peer-reviewed manuscript. The published version may be accessed by following the link in the citation at the bottom of the page.

Table 1: Study participants

\begin{tabular}{|c|c|c|c|c|c|}
\hline Name & Age & Teaching Position & $\begin{array}{l}\text { Years } \\
\text { Teaching }\end{array}$ & $\begin{array}{c}\text { Prior Online } \\
\text { Learning? }\end{array}$ & $\begin{array}{c}\text { Self-reported Technology } \\
\text { Experience }\end{array}$ \\
\hline Elizabeth & 30 & $\begin{array}{l}\text { HS English } \\
\text { Private, Urban }\end{array}$ & 6 & $\begin{array}{l}\text { Online } \\
\text { discussions }\end{array}$ & $\begin{array}{l}\text { Advanced: Web pages, } \\
\text { presentation tools, } \\
\text { graphics, multimedia; } \\
\text { email, IM }\end{array}$ \\
\hline Maria & 28 & $\begin{array}{l}\text { College Spanish } \\
\text { Private }\end{array}$ & 6 & $\begin{array}{l}\text { One online } \\
\text { course }\end{array}$ & $\begin{array}{l}\text { Medium: e-mail; Web } \\
\text { pages, presentation tools }\end{array}$ \\
\hline Tina & 44 & $\begin{array}{l}\text { HS Spanish } \\
\text { Public, Suburban }\end{array}$ & 2 & No & Beginning: e-mail \\
\hline Dan & 28 & $\begin{array}{l}\text { MS Social Studies } \\
\text { Urban }\end{array}$ & 5 & No & $\begin{array}{l}\text { Advanced: Multimedia; } \\
\text { computerized graphic } \\
\text { design, databases, } \\
\text { e-mail, IM }\end{array}$ \\
\hline Robert & 27 & $\begin{array}{l}\text { MS English } \\
\text { Urban }\end{array}$ & 2 & $\begin{array}{l}\text { Online } \\
\text { discussions }\end{array}$ & $\begin{array}{l}\text { Medium: Presentation } \\
\text { tools, e-mail, IM }\end{array}$ \\
\hline Tom & 53 & $\begin{array}{l}\text { MS Math } \\
\text { Urban }\end{array}$ & 11 & No & $\begin{array}{l}\text { Medium: Presentation } \\
\text { tools, multimedia files, } \\
\text { e-mail, IM }\end{array}$ \\
\hline
\end{tabular}

Note: $\mathrm{HS}=$ High school; $\mathrm{MS}=$ Middle school; $\mathrm{IM}=$ Instant Messenger 
NOT THE PUBLISHED VERSION; this is the author's final, peer-reviewed manuscript. The published version may be accessed by following the link in the citation at the bottom of the page.

\section{Table 2: Traditional and adapted self-regulated learning (SRL) strategies used by online learners.}

\begin{tabular}{|c|c|c|}
\hline SRL Strategies & Traditional & Online Adaptations \\
\hline \multicolumn{3}{|l|}{ Forethought } \\
\hline Goal setting \& planning & $\begin{array}{l}\text { Calendars and organizers; } \\
\text { self-imposed deadlines; chunking } \\
\text { work }\end{array}$ & $\begin{array}{l}\text { Daily log ons; coordination of } \\
\text { online and off-line work; planning } \\
\text { for tech. problems }\end{array}$ \\
\hline \multicolumn{3}{|l|}{ Performance \& } \\
\hline $\begin{array}{l}\text { Organizing \& transforming } \\
\text { instructional materials }\end{array}$ & $\begin{array}{l}\text { Notetaking; outlining; underlining } \\
\text { or highlighting course texts; } \\
\text { graphic organizers }\end{array}$ & $\begin{array}{l}\text { Printing out course materials and } \\
\text { discussions; off-line composing } \\
\text { and editing of postings; sorting } \\
\text { discussion threads }\end{array}$ \\
\hline $\begin{array}{l}\text { Structuring the learning } \\
\text { environment }\end{array}$ & $\begin{array}{l}\text { Reducing distractions; relaxation } \\
\text { techniques }\end{array}$ & $\begin{array}{l}\text { Finding fast computer and Internet } \\
\text { connection; creating a } \\
\text { psychological place in class }\end{array}$ \\
\hline Help-seeking & $\begin{array}{l}\text { Phone, e-mail, or personal contact } \\
\text { to get help from instructor or peers }\end{array}$ & $\begin{array}{l}\text { Accessing technical expertise; } \\
\text { peer contacts to reduce loneliness; } \\
\text { Web-based helpers; using student } \\
\text { postings as models }\end{array}$ \\
\hline $\begin{array}{l}\text { Self-monitoring \& } \\
\text { record-keeping }\end{array}$ & $\begin{array}{l}\text { Charts and records of completed } \\
\text { assignments and grades }\end{array}$ & $\begin{array}{l}\text { Multiple back ups; tracking reading } \\
\text { and writing for discussions; } \\
\text { frequent checks of online } \\
\text { gradebook }\end{array}$ \\
\hline \multicolumn{3}{|l|}{ Self-Refiection } \\
\hline Self-judgment & $\begin{array}{l}\text { Using checklists and rubrics; using } \\
\text { instructor comments and grades }\end{array}$ & $\begin{array}{l}\text { Using audience of peers to shape } \\
\text { discussion }\end{array}$ \\
\hline Self-reactions & $\begin{array}{l}\text { Success based on academic } \\
\text { performance }\end{array}$ & $\begin{array}{l}\text { Success based on technical, } \\
\text { social, academic performance }\end{array}$ \\
\hline
\end{tabular}

Educational Technology Research and Development, Vol. 52, No. 4 (2004): pg. 5-21. DOI. This article is (C) Springer and permission has been granted for this version to appear in e-Publications@Marquette. Springer does not grant permission for this article to be further copied/distributed or hosted elsewhere without the express permission from Springer. 